\title{
A Conversation with Susan Gasser
}

\author{
INTERVIEWER: JAN WITKOWSKI
}

Cold Spring Harbor Laboratory

\begin{abstract}
Susan Gasser is a Professor of Molecular Biology and Director of the Friedrich Miescher
\end{abstract} Institute for Biomedical Research at the University of Basel.

Jan Witkowski: Perhaps we could begin with a synopsis of your work.

Dr. Gasser: We've been studying the mechanisms of heterochromatin repression, of different ways to keep genes silent. Most of that is at the level of transcription through the formation of heterochromatin, but in a screen for derepression of heterochromatin we found three subunits of an RNA-controlling complex. All the other hits in this screen were chromatin modulators as we expected, so these three were a surprise. This was in C. elegans, but this complex is conserved from bacteria to yeast to humans. It's called the LSM complex for "like Sm" proteins.

We read up on the LSm complex, and found that it comes in two forms. There's one in the cytoplasm and another in the nucleus. They share six subunits, but the seventh, either subunit 1 or 8 , is specific for either cytoplasm or nucleus. The first thing we showed was that the role in silencing was through the nuclear complex. That was good, because it meant that it was probably working at the level of genes.

We then looked at the proteins that are supposedly interacting with this nuclear complex. Its normal role is to bind U6 RNA, catalyze or chaperone splicing, and then help trigger the degradation of the spliced-out intron, through an RNA exonuclease called XRN2. XRN2, but not U6 RNA, was also involved in the heterochromatic silencing of our reporter.

Then we asked, "Which endogenous genes are sensitive to this RNA degradation mode of silencing?" We detected several hundred genes that were derepressed - or up-regulated - in the absence of this LSM complex or of XRN2. We asked, "What's the nature of these genes?" First, we saw that they were all very poorly expressed in wild-type worms. Second, we checked their chromatin state by monitoring enrichment of histone marks, and we found that 95\% carried histone $\mathrm{H} 3 \mathrm{~K} 27 \mathrm{me} 3$, the characteristic methylation deposited by Polycomb.

Polycomb is known to silence genes. It's usually thought to create facultative heterochromatin in a tissueor cell type-specific manner. It actually poises genes in an "off" state, but such that they can also be switched "on," depending on differentiation. It's quite intriguing that all the genes that were controlled by this LSM2-8 were Polycomb-marked facultative heterochromatin. So we were faced with the question, "How does it work?" Polycomb normally represses by transcriptional repression, by blocking transcription, but here we were looking at RNA degradation. We checked specific genes that were sensitive to this RNA-degrading complex and showed that if you mutate the LSM8 subunit, which is specific for the XRN2-binding nuclear complex, then you stabilize a low level of transcripts from such target genes. Apparently, although genes are repressed by Polycomb, there's a low level of promiscuous transcription possible. Then we asked if the same genes are regulated by XRN2, LSM8, and Polycomb. And indeed, they overlap significantly.

Finally, we asked the question, "Does RNA degradation feed back in any way to the Polycomb mark?" Does the LSM complex and RNA degradation stabilize the transcriptional repression that's mediated by Polycomb?" And indeed it does; we see that the K27 methylation mark is reduced on target genes, but not lost overall, in the $l s m-8$ mutant. The LSM8 complex constitutes a backup system that ensures the integrity of the Polycomb repression pathway. This is rather a noncanonical idea, and the Polycomb field seems not very keen on having Polycomb silence by means of something other than the attenuation of Pol II [DNA polymerase II] activity. So it's been an interesting ride to try to publish this.

Jan Witkowski: Does LSM just mop up this low-level transcription?

Dr. Gasser: Right. We believe that it degrades breakthrough transcripts, and usually full-length message. At least, the RNAs we recover are not enriched for the Ntermini of the genes. There must be a decapping enzyme that allows the exonuclease XRN2 to degrade the transcript. It's basically reducing the steady state level-often four- to tenfold - from a background level that stems from the incomplete silencing of Polycomb-marked genes. Actually, it is known that Polycomb-marked genes are not $100 \%$ "off." Repetitive centromeric heterochromatin, for example, can be more completely "off."

(C) 2019 Gasser. This article is distributed under the terms of the Creative Commons Attribution-NonCommercial License, which permits reuse and redistribution, except for commercial purposes, provided that the original author and source are credited. 
Jan Witkowski: Is the target gene really repressed?

Dr. Gasser: I would say it's quite repressed - or silent - if you have both transcriptional repression and the elimination of promiscuous transcripts. When we knock out this secondary pathway in C. elegans, the animals are still alive, but their gonadal development is impaired and they become sterile. So if you ask, "How important is it?," it is likely to be very important, as the organism can't reproduce without it.

Jan Witkowski: Is this the first example of this sort of mopping up?

Dr. Gasser: It's been observed and even characterized very well in Schizosaccharomyces pombe-fission yeast - and in plants, where it occurs at centromeric satellite repeats. However, it involves a different pathway, because it depends on a reverse transcriptase that makes a doublestranded RNA that is "diced" and bound by an Argonaute. The Argonaute-dsRNA comes back and helps nucleates H3K9 methylation, which is the canonical repressive mark on constitutive heterochromatin. So, the concept that a promiscuous transcript can feed back and help stabilize repression was already in the field, but it had never been demonstrated or characterized beyond fission yeast and plants. This is the first example in animals, and the first time the Polycomb system and the LSM complex are implicated.

Jan Witkowski: C. elegans is a worm. Is it also true of mice and man?

Dr. Gasser: We've just initiated this study. Of course, the complex is conserved and we found that human LSM8 can be bound to chromatin and associates with XRN2. We've just done the RNA-seq to see the genes that are misregulated. We haven't fully characterized the data, but there are genes that both go up and down. Now we're checking to see if targets bear the Polycomb mark.

Jan Witkowski: The subunit 8 of LSM is the one that makes it nuclear, and subunit 1 makes it cytosolic. Are these carrying some sort of signal?

Dr. Gasser: The complex as a whole recognizes poly(A) message in the cytoplasm. In the nucleus, when it recognizes the U6 snRNP [small nucleolar ribonucleoprotein] it recognizes a small poly(U) stretch. We don't really know if there is a signal on these Polycomb-repressed genes somewhere in the $3^{\prime}$ UTR [untranslated region] that's actually recognized by this LSM2-8 complex, but it's clear that you could call this complex "structural," because in both cases - nuclear and cytoplasmic - its job is to bring in an exonuclease. In the cytoplasm, it degrades messages; in the nucleus, it degrades messages and introns. The real link we are missing is the mechanism that targets it to this class of genes. How does it recognize the transcripts of Polycomb-marked genes? We don't know if it's a feature of the RNA or if there is a link to the histone modification. mRNAs could be aberrantly capped or could have some secondary structure or motif. It doesn't seem to be 3' UTR-specific, as we've swapped 3' UTRs. Anyway, there are hundreds of genes that are regulated this way, so it's not one single UTR motif. We're looking for the signal.

Jan Witkowski: You used the term "noncanonical" earlier. Is RNA a more interesting molecule than DNA?

Dr. Gasser: Oh, I don't know. The combination is fascinating and I think there are many variants of DNA that we haven't actually explored. There are modifications like methylation, but also sequence motifs, sequence variation, secondary structures, and many selfish repetitive elements, the behavior of which is still not understood. I'm still fascinated with DNA and chromatin, but RNA is interesting, and has unexpected roles. The simple message that we heard about mRNA 50 years ago is pretty much water under the bridge.

Jan Witkowski: Your institute was founded by CibaGeigy.

Dr. Gasser: Next year, it's 50 years, and we've been funded by industry for 50 years. First it was Ciba-Geigy and then Novartis; they've been extremely generous. Initially costs were covered $100 \%$, but in the last 15-20 years, about $70 \%$. We compete for grants, which keeps us linked to the academic world. The fabulous thing is that for all that time, they've never told us what to study. We pursue fundamental discovery research, although we are funded by industry. Fortunately, it's one of those rare instances in which the value of open-ended research and the strength of curiosity-driven discovery are recognized.

Jan Witkowski: Is the institute unique in these things?

Dr. Gasser: The Institute of Molecular Pathology in Vienna is funded by Boehringer Ingelheim in a very similar manner. BI even has a second smaller Institute in Mainz, which is near their headquarters. I keep trying to convince other companies that this is the way to go, that they could have a hotline to clever scientists this way. The energy of discovery-driven science is something that keeps a company on its toes, challenging the ideas that sometimes become inbred and narrow within drug development. Very often, they need to be shaken out of their ways of thought, just as basic scientists do. At least in our case, wisdom and vision from the company's leader has kept us alive and hopefully will for another 50 years. 


\section{$\$_{\text {CSH\& }}^{\infty}$ Cold Spring Harbor Symposia SYMPOSIA on Quantitative Biology}

\section{A Conversation with Susan Gasser}

Cold Spring Harb Symp Quant Biol published online January 3, 2020

Access the most recent version at doi:10.1101/sqb.2019.84.039214

$\mathbf{P}<\mathbf{P} \quad$ Published online January 3, 2020 in advance of the print journal.

Creative This article is distributed under the terms of the

Commons http://creativecommons.org/licenses/by-nc/4.0/, which permits reuse and

License redistribution, except for commercial purposes, provided that the original author and source are credited.

Email Alerting

Receive free email alerts when new articles cite this article - sign up in Service the box at the top right corner of the article or click here.

Advance online articles have been peer reviewed and accepted for publication but have not yet appeared in the paper journal (edited, typeset versions may be posted when available prior to final publication). Advance online articles are citable and establish publication priority; they are indexed by PubMed from initial publication. Citations to Advance online articles must include the digital object identifier (DOIs) and date of initial publication.

To subscribe to Cold Spring Harbor Symposia on Quantitative Biology go to: http://symposium.cshlp.org/subscriptions 